\title{
Book Review: Anita Mackay, Towards Human Rights Compliance in Australian Prisons
}

Matthew Groves ${ }^{\mathbb{D}}$, Alfred Deakin Professor, Deakin University Law School, Australia

\begin{abstract}
Book Review: Anita Mackay, Towards Human Rights Compliance in Australian Prisons, Canberra: Australian National University Press, 345pp + xxii, ISBN: 9781760464004.

Keywords - Book review, human rights compliance, prisons, prison reform

Acknowledgments. This book was provided free of charge by ANU Press.

Disclosure statement. No potential conflict of interest was reported by the author.

License. This work is under Attribution-NonCommercial-ShareAlike 4.0 International (CC BY-NC-SA 4.0)

https://creativecommons.org/licenses/by-nc-sa/4.0/

Suggested citation: Groves, M. 2021. "Book Review: Towards Human Rights Compliance in Australian Prisons, by Anita Mackay". Law in Context, 37 (2). DOI: http://doi.org/10.26826/law-in-context.v37i2.160
\end{abstract}

For a long time, Australian legal analysis of prisoners' rights had what can fairly be described as a backwardlooking approach. The focus of courts and government officials was usually directed to how longstanding legal doctrines inherited from England, applied in Australia. A notorious example of recent history was the High Court's decision in Dugan v Mirror Newspapers Ltd,1 which affirmed the medieval English doctrine of attainder or 'civil death'. The immediate consequence of the attainder doctrine in that case was to prevent a convicted felon from commencing or maintaining a proceeding in the civil courts. The superficial rationale adopted by the High Court was the unsatisfactory one that any decision which enabled those convicted of a felony offence to access to the courts was so serious a step that it was best taken by parliament. This justification was all the more unsatisfactory because it was invoked by the High Court in the very same year it had declared itself no longer bound by decisions of the Privy Council.2 The immediate paradox was that the High Court had freed itself from the yoke of the Privy Council, yet happily countenanced the continued operation of principles created and enforced by that same structure. The deeper and more unsatisfactory implication of Dugan was its acceptance that prisoners should be denied basic civil rights and could expect no sympathy from the courts.

Anita Mackay begins her excellent book by returning much further in the past, to a time when Australia was at the forefront of prison reform. This was the short but important reign of Alexander Maconochie as the Governor of Norfolk Island, which began in 1840. Maconochie accepted the radical idea that prisoners could be rehabilitated and sought to implement the even more

(1978) 142 CLR 583. Murphy J delivered a spirited dissent, which drew heavily upon European and American human rights law.

Viro v R (1978) 141 CLR 88. This decision was delivered eight months before Dugan. 
radical idea that prison officials should seek to facilitate that goal. English authorities could not tolerate such heresy, even in the outer reaches of Australia. Maconochie was ordered to return to London and his reformative dream largely left with him. Mackay notes in her introduction that both the ideas of Maconochie and the response that quelled them still swirl in Australia almost two centuries later. The Australian Capital Territory named its prison after Maconochie, clearly signalling the enduring value of his reformative ideals, and yet much of our law and politics about criminal justice and prisons is shaped by those who 'valorise punishment' (p. 3). The depressing context of that valorisation of punishment is explained in the first chapter, where Mackay explains the key aspects of Australia's prison population. The multiple disadvantages experienced by many, perhaps even most, prisoners raise some obvious questions. Why focus so much effort on prison regimes that will very likely continue the problems most prisoners have faced? Why set prisoners up for more failure in life?

Mackay examines these underlying questions through an analysis that marks a clear departure from the backward-looking approach noted above. Her guiding question is not so much what is wrong with Australian prisons and their surrounding legal framework, but rather a detailed consideration of what Australia ought to do order to comply with the international law and other human rights standards to which we are subject (p. 7). This forward looking and aspirational approach sets this book apart from some of its international equivalents. Perhaps the most obvious is Livingstone, Owen and McDonald on Prison Law, 3 which has dominated United Kingdom prison law for over two decades. Similar works from America and Europe analyse the domestic public law, and the domestic and international human rights law, that have shaped prisons in other jurisdictions. Australia remains such an outlier on the human rights elements of this law as far as it applies to prisons, that Mackay's book is as much about how human rights regimes could change Australian prisons and the lives of prisoners, as it is the extent to which they already have.

This almost bifurcated analysis is a wise methodology for Australia's prisons, because they stand at an odd juncture. Australia lacks a uniform federal prison system, 4 which means there are still eight different legal frameworks governing prisons in our states and territories, but there is a tide of uniformity as regards some aspects of human rights. Australia ratified the Optional Protocol to the United Nations Convention Against Torture and Other Cruel, Inhuman or Degrading Treatment or Punishment on 21 December 2017. The Human Rights Act 2019 (Qld) commenced on 1 January 2020. These twin events signal that the enactment of the $\mathrm{Hu}-$ man Rights Act 2004 (ACT) and the Charter of Human Rights and Responsibilities Act 2006 (Vic) are no longer anomalous. Australia is approaching a tipping point, where the majority of its prisons and prisoners will be subject to meaningful human rights protection. Mackay has carefully mapped the steps that have taken Australian prisons to this point, as well what might likely occur should a more uniform approach develop.

The first chapter provides a useful, though somewhat depressing narrative of the state of Australia's prisons and their occupants. The immediate value of the chapter is to provide an overview of a very fragmented system, but the real purpose of the chapter is to map the key changes required for human rights compliance in prisons. The two chapters that follow, which make up the remainder of the first part of the book, analyse the international human rights obligation to which Australia is subject and the nature and potential changes that accession to the Optional Protocol to the Convention Against Torture may bring. One striking feature of these two chapters is how they lay bare the

3 Tim Owen and Alison McDonald (eds), Livingstone, Owen and McDonald on Prison Law ( $5^{\text {th }}$ ed, OUP, 2015). The first edition of this book was published more than twenty years earlier.

4 Section 120 of the Australian Constitution obliges the states to house prisoners held under federal authority. The Commonwealth could clearly introduce a separate federal correctional legislative regime, or build its own prisons, but it has not done so though one could argue that immigration detention centres are in fact our federal prison system. 
inadequacies in Australia's correctional statutes and policies. Mackay makes a compelling argument that the absence of enforceable rights within those many statutes is only one of their many shortcomings. The force of this argument is amplified by the meticulous attention given to the vast body of work that occurs outside the courts - official reports of coronial inquiries, investigations by ombudsmen and other integrity bodies. These non-judicial avenues constitute the vast bulk of review and accountability for Australian prisons and Mackay draws upon them masterfully. The analysis is thorough but not overburdened with detail, drawing from a vast array of sources but never swaying in its focus.

The remaining chapters are divided into two thoughtfully that the relentless growth of our prison population, which occurred almost entirely because of state criminal law practices, is as destructive for society as it is for its victims. The book is greatly improved by this integration of an argument that would traditionally be regarded as the domain of criminologists. This overarching constructed parts - the macro and micro level prerequisites to rights compliance in Australian prisons. The chapters that examine macro-level issues include a thoughtful one about the need to reduce Australia's reliance on imprisonment. Mackay makes a compelling argument point is continued in the last part of the book, which deals with the micro-level prerequisites for greater human rights compliance. Mackay analyses the two most important but also most overlooked aspects of prisons - prison staff and prison buildings. The two chapters that deal with staff and prison buildings continue a key feature of the book, being the finely judged balance between cataloguing a dismal range of Prob- lems, whilst also providing a framework for reform that is as practical as it is legally sound. This striking emphasis on the practical dimension of prison reform draws the book into the realm of public policy, which may be its greatest strength. Mackay marshals an enormous amount of material from many jurisdictions and disciplines, but the book is as readable for a prison guard as it is for a judge.

It seems appropriate to conclude this review with a note on a note. The note in question is one Mackay makes in her introduction, where she explains her preference for terms such as 'imprisoned persons' or 'person in prison'. Mackay rightly notes that labels carry power. When we refer to people as a 'prisoner' or an 'offender' or any other label, we 'risk subtly justifying substandard, inhumane or less-than-optimal treatment-the very opposite of the book's purpose' (p. 8). This might seem a small point, but it is not. After reading this book, I revisited the Dugan case. I have read that case dozens of times during my own study of prison law, though it was only Mackay's reminder of the value of words and labels that made me notice that the High Court never once referred to Mr Dugan by his own name. He was the 'felon', the 'convict' or the 'prisoner'. How had that small but revealing fact passed me by for so long? The uncomfortable answer is that you cannot see what you do not even know to look for. This ostensibly minor point draws attention to the wider significance of Mackey's valuable book. The careful and detailed analysis makes the book an important work for those interested in prisons. It is Mackay's fresh and thoughtful take on so many issues that make the book an essential one for anyone who studies, work or lives in prisons. 